\title{
Desarrollo de mezclas de hormigón poroso para pavimentos urbanos permeables
}

\section{Porous concrete mixtures for pervious urban pavements}

\author{
H. de Solminihac ${ }^{(*)}$, C. Videla ${ }^{(*)}$, B. Fernández ${ }^{(*)}$ y $\underline{\text {. Castro }}^{*)}$
}

Recepción/Received: 11-VII-06 Aceptación/Accepted: 14-II-07

RESUMEN

El trabajo realizado en este estudio consistió en analizar el comportamiento de diferentes dosificaciones de mezclas de hormigón poroso, fabricadas en laboratorio y compactadas con rodillo pesado para simular las condiciones de terreno. Las variables consideradas para el diseño de las mezclas fueron el porcentaje real de huecos en el hormigón endurecido y la razón agua/cemento. A partir de estos resultados se determinaron las dosificaciones que presentan mejor comportamiento desde el punto de vista mecánico e hidráulico.

Los resultados muestran que existe una dosificación de hormigón poroso, distinta a las encontradas actualmente en la literatura internacional, que permite obtener resistencias hasta $20 \%$ más altas, manteniendo todavía una excelente capacidad hidráulica. Se determinó que una permeabilidad suficiente se puede obtener con un porcentaje real de huecos de $14 \%$, y que agregar pasta de cemento en una proporción de $250 \mathrm{l} / \mathrm{m}^{3}$ permite maximizar la resistencia a flexotracción de hormigones que utilizan diferentes razones a/c. Se encontraron relaciones entre el porcentaje de huecos y la permeabilidad del material, y entre el porcentaje de huecos y la resistencia a flexotracción a 28 días.

Palabras clave: hormigón poroso, hormigón permeable, hormigón drenante, permeabilidad, infiltración.

\section{SUMMARY}

The present study aimed to analyze the hydraulic and mechanical behaviour of a series of roller-compacted, laboratory porous concrete mixtures. The mix design variables examined were the actual void ratio in the hardened concrete and the water/cement ratio. From these results the better dosages from the mechanical and hydraulical behaviour point of view were determined.

One of the designs developed was found to exhibit exceIlent hydraulic capacity and $20 \%$ greater strength than the mixtures recommended in the literature. Moreover, concrete with an actual void ratio of only $14 \%$ was observed to meet permeability requirements. Maximum flexural strength of concretes with different $\mathrm{w} / \mathrm{c}$ ratios was achieved with a cement paste content of $250 \mathrm{l} / \mathrm{m}^{3}$. Relationships were found between the void ratio and both 28-day concrete permeability and flexural strength. Finally, the doses exhibiting the best mechanical and hydraulic performance were identified.

Keywords: porous concrete, pervious concrete, drain concrete, permeability, infiltration.

(*) Pontificia Universidad Católica de Chile (Santiago, Chile). 


\section{INTRODUCCIÓN}

A medida que las ciudades crecen y se desarrollan, aumentan las áreas urbanizadas. Se construyen viviendas y se pavimentan nuevas calles, existiendo cada vez mayor cantidad de superficies impermeables. Esta situación impacta negativamente en la infiltración natural del terreno, lo que se traduce en aumentos de los volúmenes de escorrentía y de los caudales máximos a evacuar cada vez que llueve.

Para solucionar estos problemas se necesitan cuantiosas inversiones en la construcción de sistemas de colectores. Sin embargo, si las ciudades siguen creciendo bajo el concepto tradicional de evacuar lo más rápido posible las aguas de lluvia desde el lugar en donde se generan, y si todos los esfuerzos se concentran en las consecuencias y no en las causas que producen las inundaciones, tarde o temprano el sistema de colectores diseñado se hará insuficiente.

Para atenuar estos efectos, en los últimos años se ha desarrollado a nivel mundial un modo alternativo de diseñar los pavimentos de estacionamientos y calles de bajo tránsito, construyendo estructuras que permiten el paso del agua a través de la capa superficial hacia su interior, donde se almacena para ser infiltrada si el terreno lo permite, o para ser conducida a un sistema de recolección de forma controlada. De este modo, se disminuye la acumulación de agua en su superficie y el escurrimiento superficial aguas abajo.

En este trabajo se presenta el estudio de hormigones porosos, fabricados en laboratorio compactados de forma similar a como se realiza en terreno. A partir de estos resultados se definen dosificaciones que maximizan las propiedades estructurales e hidráulicas de este material.

\section{IMPORTANCIA DE LA INVESTIGACIÓN}

Si bien existe información del uso de hormigones para este tipo de pavimentos desde hace 15 años, incluyendo dosificaciones y recomendaciones constructivas, no existen hasta ahora investigaciones que utilicen un sistema de compactación similar al usado en terreno para caracterizar el comportamiento del material. Los autores creen que los resultados de este trabajo permitirán caracterizar de mejor forma el comportamiento de este hormigón fresco, lograr mayor certeza sobre el comportamiento mecánico e hidráulico en estado endurecido, y optimizar el uso del cemento para lograr las mayores resistencias a flexotracción para cada razón agua/cemento.

\section{INTRODUCTION}

The growth and development of cities goes hand-inhand with urban sprawl. New housing is built and new streets are paved, with a concomitant increase in impervious surface cover. This scenario has an adverse impact on natural percolation, raising maximum runoff flow rates after rains and intensifying the effects of flooding.

The solution to such problems calls for substantial investment in stormwater collection systems. If this traditional approach to urban growth is maintained, i.e., evacuating stormwater as quickly as possible, and efforts continue to focus on the consequences rather than the causes of flooding, the existing water collection systems will eventually prove to be insufficient.

In recent years, an alternative pavement design has been developed the world over for parking lots and streets where traffic is light to mitigate these effects. Such pavements allow stormwater to percolate from the surface through the inner layers and into the soil below, if permeable, and to a drainage collection system otherwise, thereby reducing the water accumulating on the surface and downstream surface runoff.

The present paper discusses a study of porous concrete made in the laboratory and compacted under field conditions. Doses that optimize the structural and hydraulic properties of this material are defined on the basis of the results obtained.

\section{RELEVANCE OF THE RESEARCH}

While information on impervious concrete pavements, including dosage and construction procedures, has been available for 15 years, no research has yet been conducted on concrete compacted as it would be on the worksite to characterize behaviour. The results of the present study will help improve fresh porous concrete characterization, determine hardened concrete mechanical and hydraulic properties with greater certainty and optimize cement content to attain the highest flexural strength (modulus of rupture) for a given water/cement ratio. 


\section{PROGRAMA EXPERIMENTAL}

\subsection{Fundamentos para definir el trabajo en laboratorio}

La principal característica de una mezcla porosa es su capacidad de infiltración. La permeabilidad de estas mezclas se obtiene usando áridos con un volumen significativo de huecos entre las partículas y con ausencia casi total de finos, y una cantidad reducida de pasta de cemento. La resistencia del material se obtiene mediante el efecto combinado de la delgada capa de pasta de cemento y la transmisión de esfuerzos por contacto entre los áridos (1).

La pasta de cemento adicionada puede tener diferentes propiedades (diferente razón a/c), y puede ser agregada en diferentes proporciones. Las propiedades mecánicas e hidráulicas del hormigón endurecido, dado un sistema de compactación, dependerán de las características de la pasta y del porcentaje de huecos reales interconectados en la mezcla que se logra con cada dosificación.

\subsection{Materiales}

Se utilizaron áridos sin finos, granulometría no 8 tamaño máximo nominal de $10 \mathrm{~mm}$ según norma ASTM C33 (2, $3,4)$, con peso específico de $1.520 \mathrm{~kg} / \mathrm{m}^{3}$, un porcentaje de huecos de $43 \%$, y absorción del árido de 1,6\%. Se usó cemento Portland puzolánico de alta resistencia inicial con densidad $2.950 \mathrm{~kg} / \mathrm{m}^{3}$ y aditivo plastificante reductor de agua en dosis de $0,5 \%$ del peso del cemento con densidad $1,16 \mathrm{~kg} / \mathrm{m}^{3}$.

\subsection{Variables experimentales}

Las variables independientes consideradas fueron el porcentaje real de huecos y la razón agua/cemento $(\mathrm{a} / \mathrm{c})$ de la mezcla. Según la literatura existente $(2,3,4)$, las mezclas permeables deben tener como mínimo un $15 \%$ de huecos. Sin embargo, a juicio de los autores, la tasa de infiltración de las mezclas es muy importante también. Las mismas investigaciones permiten establecer que asociado a un $15 \%$ de huecos se encuentra una tasa de infiltración cercana a 3,5 mm/s, valor determinado realizando un ensayo de permeabilidad de carga variable a probetas cilíndricas de $15 \mathrm{~cm}$ de diámetro y $15 \mathrm{~cm}$ de altura, impermeabilizadas lateralmente y colocadas dentro de un tubo de plástico del doble de la altura de las probetas, sobresaliendo 7,5 $\mathrm{cm}$ en cada extremo. Este valor de 3,5 mm/s será considerado en este trabajo como la mínima tasa de infiltración aceptable para considerar como porosa a una mezcla.

Adicionalmente, Meininger (5) señala que las mezclas con un contenido de huecos de entre 15 y $20 \%$ permiten obtener mezclas con una adecuada resistencia y permeabilidad.

\section{EXPERIMENTAL}

\subsection{Laboratory experiments}

The main characteristic of porous concrete mixtures is their permeability, which is obtained by using aggregate with a significant volume of voids, virtually no fines and a low cement paste content. Concrete strength is the result of the combined effect of cement paste bonding and the transmission of stress across aggregate particles (1).

Different proportions of cement paste with different w/c ratios may be used. For a given compaction system, the strength and hydraulic properties of the hardened concrete depend on paste characteristics and the actual percentage of continuous voids attained with each dosage.

\subsection{Materials}

Coarse (No. 8) aggregate with no fines and a 10- $\mathrm{mm}$ maximum nominal size was used, pursuant to ASTM C33 $(2,3,4)$. The dry compacted bulk density was 1520 $\mathrm{kg} / \mathrm{m}^{3}$, the void percentage $43 \%$ and water absorption 1.6\%. Rapid-hardening Portland cement with a bulk density of $2,950 \mathrm{~kg} / \mathrm{m}^{3}$ was used, to which a water-reducing admixture $(0.5 \%$ by cement weight) with a bulk density of $1.16 \mathrm{~kg}$ was added.

\subsection{Variables studied}

The independent variables studied were the actual percentage of voids in the mixture and the water/cement (w/c) ratio. According to the literature (2, 3, 4), pervious mixtures should have a void ratio of at least $15 \%$. The infiltration rate is also regarded to be important, however. Further to these same studies, a $15 \%$ void ratio is associated with an infiltration rate of around $3.5 \mathrm{~mm} / \mathrm{s}$. This value was found with a falling head permeameter applied to $15-\mathrm{cm}$ diameter, $15-\mathrm{cm}$ high cylindrical specimens, waterproofed on the sides and placed inside plastic tubes double their height that projected $7.5 \mathrm{~cm}$ on each end. The value found, i.e., $3.5 \mathrm{~mm} / \mathrm{s}$, was taken in the present study to be the minimum acceptable infiltration rate for a porous mixture.

Moreover, Meininger (5) reported that mixtures with a void ratio of between 15 and 20\% yielded permeable, medium strength concrete. Consequently, concretes with 
Por esta razón, se escogió utilizar hormigones con 15, 17 y $19 \%$, con el fin de analizar el efecto de esta variable sobre la resistencia y permeabilidad de las mezclas.

La variable a/c se fijó en 0,29; 0,32;0,35;0,38; 0,41 y 0,44 . Estos valores fueron escogidos para obtener un rango de mezclas, desde muy secas con alta permeabilidad pero baja resistencia, hasta mezclas más fluidas con menores permeabilidades y mayores resistencias.

La dosis de cemento se determinó, para cada dosificación, en función del porcentaje de huecos y la razón a/c, de la forma en que se presenta a continuación.

\subsection{Sistema de dosificación}

En teoría si se utiliza una granulometría con porcentaje de huecos del orden del $40 \%$, y se agrega un volumen de pasta de cemento del orden de $25 \%$, habrá huecos suficientes para que la pasta se introduzca en ellos, llenando los huecos disponibles. Así, la densidad del material se podría obtener al sumar los pesos de los componentes para un volumen dado de áridos (densidad teórica). Sin embargo, la pasta no sólo llenará los huecos del árido, sino que también se introducirá entre las partículas, separándolas e incrementando el volumen de hormigón, por lo que la densidad obtenida será menor por efecto de este "esponjamiento". Posteriormente, durante la construcción, el material se somete a la compactación por rodillo, obteniéndose la densidad real compactada. La relación entre la densidad real compactada y la densidad teórica se definió en esta investigación como Factor de Compactación (FC). A través de un desarrollo matemático se puede demostrar que el porcentaje teórico de huecos de estas mezclas se puede calcular con la Ecuación [1] (6). void ratios of 15,17 and $19 \%$ were used in this study to analyze the effect of this variable on porous concrete strength and permeability.

The water-cement ratios used were: $0.29,0.32,0.35,0.38$, 0.41 and 0.44 . These values were chosen to obtain mixtures ranging from low strength, low water-cement ratio, high permeability materials to more fluid, stronger mixtures with a high water-cement ratio and lower permeability.

The cement content was determined for each mix depending on the void and $w / c$ ratios, as discussed below.

\subsection{Dosing}

Theoretically, if $25 \%$ of cement paste, by volume, is mixed with aggregate with a particle size distribution such that the void ratio is $40 \%$, the paste will be able to fill all the voids. In such mixtures, the theoretical concrete density may be found by summing the weight of the components for a given volume of aggregate. The paste, however, not only fills the voids in the aggregate, but seeps in between particles, thereby increasing the concrete volume as a result of bulking. Roller compacting during subsequent laying of the pavement reduces the volume, therefore raising the density, although the resulting actual value is still lower than the theoretical value. In this study, the ratio between actual and theoretical density was termed the compacting factor (CF). The theoretical void ratio of such concrete can be calculated with Equation [1] (6):

$$
\begin{aligned}
& \text { porcentaje teórico de huecos }(V t)=\left(V_{a}-V_{p}\right) \cdot F C+100(1-F C) \\
& \text { theoretical percentage of capillarity voids }
\end{aligned}
$$

Donde $V_{a}$ es el porcentaje inicial de huecos del árido y $V_{p}$ es el volumen de pasta adicionada, expresados ambos valores en porcentaje.

La variable FC definida es similar a la variable b/bo (concepto usado en el ACI 211.1 para dosificar hormigones convencionales), que compara la cantidad de áridos presentes en un volumen de hormigón con la cantidad de árido presente en el mismo volumen, considerando sólo áridos secos. Sin embargo, el factor FC considera no sólo los áridos, sino también la pasta de cemento. Valores de b/bo para pavimentos porosos han sido determinados por Meininger (5), aunque utilizando métodos de compactación diferentes. De acuerdo a esa investigación los valores de b/bo son constantes para una misma energía de compactación y una curva granulométrica fija. Por esta razón el valor FC será considerado constante en esta investigación.
Where $V_{a}$ is the initial volume of voids in the aggregate and $V_{p}$ is the volume of cement paste, both expressed as a percentage of the volume of concrete.

The CF variable is similar to the $b / b o$ variable (defined in ACI 211.1 to dose conventional concretes), which compares the amount of aggregate in a volume of concrete to the same volume of dry aggregate. CF, however, includes not only the aggregate, but the cement paste as well. Meininger (5) found b/bo values for porous pavements, but using a different compaction method that did not simulate field procedures. His results showed b/bo to be constant for a given compaction energy and particle size distribution. CF was therefore regarded to be constant in this study. 
Adicionalmente, se debe considerar que en la mezcla de hormigón se generaron algunos huecos no conectados, de modo que el porcentaje de huecos del hormigón endurecido será distinto al calculado a través de la Ecuación [1]. Investigaciones previas han determinado que la relación entre el porcentaje teórico y real de huecos se puede establecer usando la Ecuación [2] (4).
Furthermore, since unconnected voids are also generated in the mixture, the percentage of voids in the hardened concrete (actual voids) differs from the percentage calculated using Equation 1 (theoretical voids). Previous research has shown that the relationship between the theoretical and actual percentage of voids is as expressed in Equation [2] (4).

porcentaje teórico de huecos $(V r)=0.898 \cdot v t-3.1$ actual percentage of capillarity voids

Considerando que la masa del concreto en estado fresco se obtiene de sumar la masa del cemento, agua, árido y aditivo, en esta investigación se ha desarrollado la Ecuación [3] para obtener la dosis de cemento de cada dosificación (6).
Equation [3] was developed to obtain the cement content needed for each mixture prepared for this study, taking the mass of the fresh concrete to be the sum of the mass of the cement, water, aggregate and admixture (6).

$$
\begin{array}{r}
\text { Cemento }(\mathrm{kg}) \\
\text { Cement content }(\mathrm{kg})
\end{array}=\left[\begin{array}{c}
(10 \mathrm{Va}-1000) F C+965.48-11.14 \mathrm{Vr} \\
\left(\frac{1}{\gamma_{c}}+(w / c)+\frac{D a d}{100 \gamma_{a d}}\right) F C
\end{array}\right]
$$

Donde $\gamma_{c}$ es la densidad del cemento, $\gamma_{a d}$ es la densidad del aditivo y Dad es la dosis del aditivo expresada como porcentaje del peso del cemento.

Para determinar el valor de FC se desarrollaron dos pruebas iniciales que indicaron que el valor de esta variable sería igual a 0,95, el que fue utilizado para las dosificaciones. El resumen de las dosificaciones utilizadas se presenta en la Tabla 1.

\subsection{Compactación y fabricación de probetas}

De acuerdo con la experiencia internacional, las mezclas de hormigón poroso deben ser compactadas con un rodillo pesado de ancho mayor que el de la losa a hormigonar $(4,6,7,8)$. Por esta razón se diseñó un rodillo de $300 \mathrm{~mm}$ de diámetro, $600 \mathrm{~mm}$ de ancho y $115 \mathrm{~kg}$ de
Where $\gamma_{c}$ and $\gamma_{a d}$ are the bulk density of the cement and admixture, respectively, and Dad is the admixture dosage expressed as a percentage of cement weight.

Two initial tests were developed to determine CF. The results showed it to be constant and equal to 0.95 , which was the value adopted for dosing. A summary of the dosages used is given in Table 1.

\subsection{Compaction and specimen preparation}

International experience has shown that porous concrete mixtures must be compacted with a heavy roller wider than the slab laid $(4,6,7,8)$. Research on such mixes should simulate that process. A roller measuring $300 \mathrm{~mm}$ in diameter and $600 \mathrm{~mm}$ wide and weighing $115 \mathrm{~kg}$ was

Tabla 1 / Table 1

Dosificaciones de los hormigones porosos confeccionados en esta investigación Porous concrete dosages used in the study

\begin{tabular}{|c|c|c|c|}
\hline \multirow{2}{*}{$\mathbf{w} / \mathbf{c}$} & \multicolumn{3}{|c|}{ Porcentaje real de huecos en la mezcla $\left(\mathbf{V}_{\mathbf{r}}\right)$ / Actual void ratio $\left(V_{r}\right)$} \\
\cline { 2 - 4 } & $\mathbf{1 5 \%}$ & $\mathbf{1 7 \%}$ & $\mathbf{1 9 \%}$ \\
\cline { 2 - 4 } & \multicolumn{3}{|c|}{ Dosis de cemento $\left(\mathbf{k g} / \mathbf{m}^{\mathbf{3}}\right) /$ Cement content $\left(\mathbf{k g} / \mathbf{m}^{3}\right)$} \\
\hline 0.29 & 427 & 390 & 353 \\
\hline 0.32 & 408 & 372 & 337 \\
\hline 0.35 & 390 & 356 & 322 \\
\hline 0.38 & 374 & 341 & 309 \\
\hline 0.41 & 359 & 328 & 297 \\
\hline 0.44 & 345 & 315 & 285 \\
\hline
\end{tabular}


peso, que proporciona presiones similares a las utilizadas en terreno $(0,08 \mathrm{MPa})$. Utilizando este rodillo, se confeccionaron probetas de $150 \mathrm{~mm}$ de espesor, $400 \mathrm{~mm}$ de ancho y $550 \mathrm{~mm}$ de largo, las que por su tamaño se denominaron losetas (Figura 1). Todas estas probetas fueron cubiertas con un plástico y dejadas a la intemperie durante 7 días, para simular las condiciones de curado de un hormigón poroso puesto en terreno.

Después, estas losetas fueron cortadas obteniendo dos probetas prismáticas de las mismas dimensiones que las usadas en los ensayos de flexotracción (150 x 150 × 550 $\mathrm{mm}$ ). Para disminuir el efecto de borde, las probetas se obtuvieron de la sección central despreciando así los 50 $\mathrm{mm}$ exteriores del ancho de las losetas.

Dieciocho dosificaciones distintas fueron analizadas. Para cada una de ellas se confeccionaron dos mezclas o "amasadas" en días diferentes (36 mezclas en total). Dos losetas fueron confeccionadas con cada amasada, con lo que 72 losetas y 144 prismas fueron fabricados en la experiencia.

\subsection{Ensayos desarrollados}

Tres diferentes ensayos fueron desarrollados: resistencia a flexotracción, determinación del porcentaje de huecos interconectados y permeabilidad o tasa de infiltración.

Dado que estos hormigones son diseñados para ser utilizados en pavimentos, se determinó realizar el ensayo de flexotracción con carga en los tercios. Ciento ocho ensayos a flexotracción fueron desarrollados (3 prismas por cada dosificación).

El porcentaje de huecos en el hormigón fue medido usando el principio de Arquímedes del peso sumergido, desarrollándose 144 ensayos (uno por cada prisma).

Para medir la permeabilidad se utilizó un permeámetro de carga variable, ensayándose las 72 losetas antes de ser cortadas (Figura 2).

\section{PRESENTACIÓN Y ANÁLISIS DE RESULTADOS}

\subsection{Factor de compactación}

Como se mencionó, para las dosificaciones se consideró un factor de compactación constante e igual a 0,95. Sin embargo, a pesar de que la literatura existente y algunas pruebas iniciales así lo indicaban, este factor resultó ser variable en la práctica. De acuerdo con la evidencia experimental obtenida en esta investigación, se determinó que este valor varía entre 0,84 y 0,99 , dependiendo therefore designed for the trials to simulate the pressure applied at the worksite (0.08 MPa). Mini-slab specimens $150 \mathrm{~mm}$ thick, $400 \mathrm{~mm}$ wide and $550 \mathrm{~mm}$ long were prepared (Figure 1). All specimens were covered with plastic and left outdoors for 7 days to simulate porous concrete curing on site.

The mini-slabs were then cut to size (150 × $150 \times 550$ $\mathrm{mm}$ ) to obtain two prismatic specimens for flexural strength testing. The prismatic samples were taken from the centre of the mini-slabs, discarding the outer $50 \mathrm{~cm}$ to minimize the edge effect.

Eighteen different concrete mixtures were analyzed. Two batches were made of each for a total of 36 samples. Two mini-slabs were made from each batch, giving a total of 72 slabs and 144 specimens.

\subsection{Tests performed}

Three tests were conducted: flexural strength, determination of the actual void ratio and permeability or the infiltration rate in hardened concrete.

Inasmuch as these concretes are designed for use in pavements, flexural strength was determined with thirdpoint loading. One hundred eight flexural tests were performed (three specimens per mixture).

The Archimedean principle on bodies immersed in a fluid was used to measure the percentage of voids in all 144 specimens (one trial was conducted per specimen).

Permeability was measured with a falling head permeameter on all 72 mini-slabs prior to division into specimens (Figure 2).

\section{ANALYSIS OF TEST RESULTS}

\subsection{Compacting factor}

As noted above, a constant factor of 0.95 was used to calculate mix proportions. Despite reports in the literature and certain initial test results, however, this factor proved to be variable in practice. Further to the experimental evidence collected in this study, the value of this parameter varied from 0.84 to 0.99 , depending primarily on the $w / c$ ratio for a given particle size distribution. The 


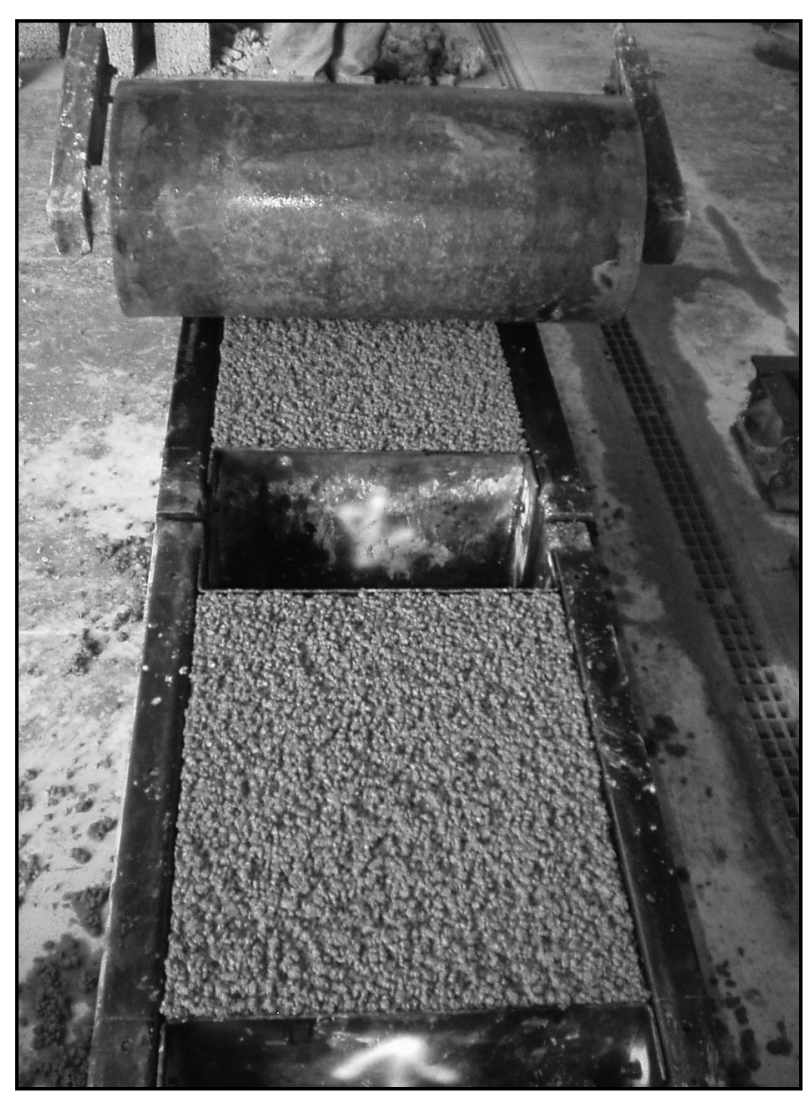

Figura 1. Compactación de las losetas en sus moldes. Figure 1. Set-up for mini-slab specimens.

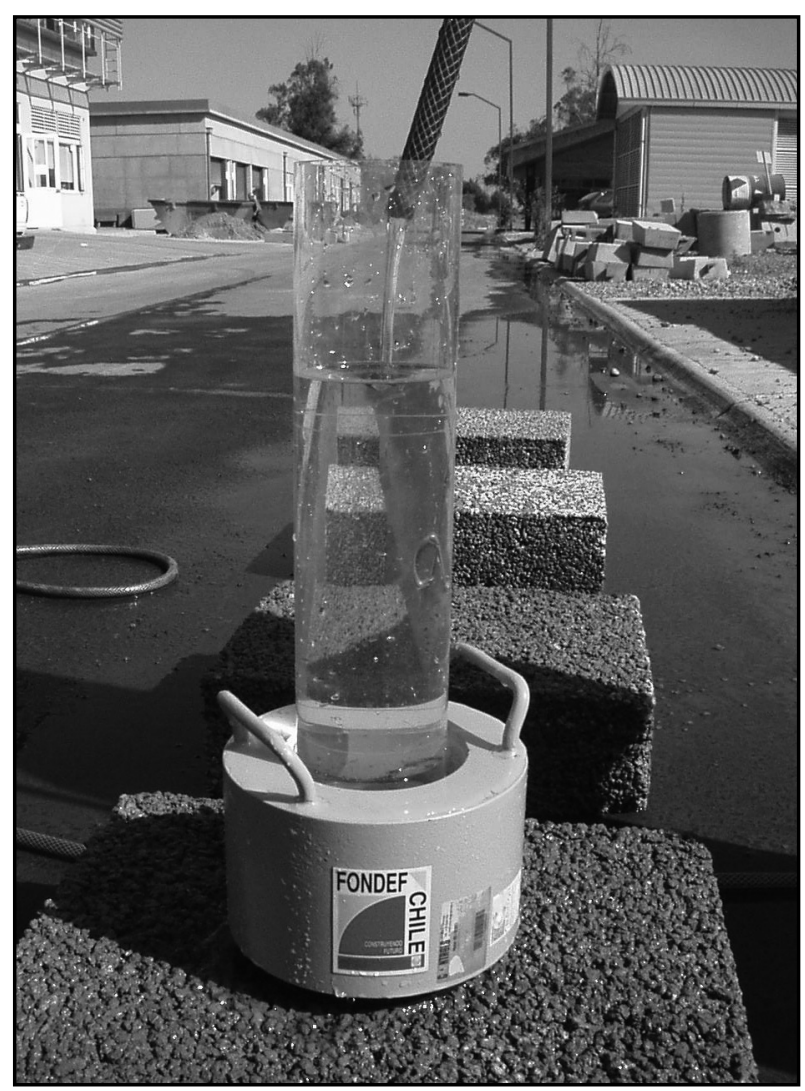

Figura 2. Ensayo con permeámetro de carga variable. Figure 2. Falling head permeameter test.

empirical relationship between compacting factor and $w / c$ ratio can be expressed as follows: principalmente de la razón a/c para una granulometría fija. A partir de los resultados obtenidos se estableció la Ecuación [4], que relaciona el Factor de Compactación real con la razón a/c.

$$
F C=-3.37 \cdot(w / c)^{2}+3.49 \cdot(w / c)+0.11 \quad\left(R^{2}=0.996\right)
$$

\subsection{Porcentaje real de huecos y permeabilidad de las mezclas}

Los resultados obtenidos utilizando el permeámetro de carga variable y el porcentaje real de huecos en el hormigón medidos con el principio de Arquímedes se presentan en la Figura 3. Un análisis de esta figura hace descartar las mezclas de razón a/c altas $(0,41$ y 0,44$)$, pues aun utilizando bajas dosis de cemento, los porcentajes reales de huecos son demasiado bajos para utilizarse como hormigones porosos. En función de este resultado, sólo se considerarán para los propósitos de esta investigación las mezclas con a/c menores o iguales a 0,38 . También puede observarse que las mezclas con contenido mayor a $14 \%$ de huecos poseen una tasa de infiltración mayor a $3,5 \mathrm{~mm} / \mathrm{s}$, con lo que se ratifican los supuestos utilizados.

\subsection{Actual percentage of concrete voids and mixture permeability}

The falling head permeameter results are plotted in Figure 3 against the actual percentage of voids in the concrete found using the Archimedean principle. An analysis of this figure shows that mixtures with high watercement ratios (0.41 and 0.44) are not suitable for porous concrete, for even when the cement content was low the actual percentage of voids was too small to use these materials in pervious pavements. On the grounds of this finding, only mixtures with w/c ratios of 0.38 or less should be used to make pervious concrete. The figure likewise shows that mixtures with a void content of over $14 \%$ had an infiltration rate higher than $3.5 \mathrm{~mm} / \mathrm{s}$. 


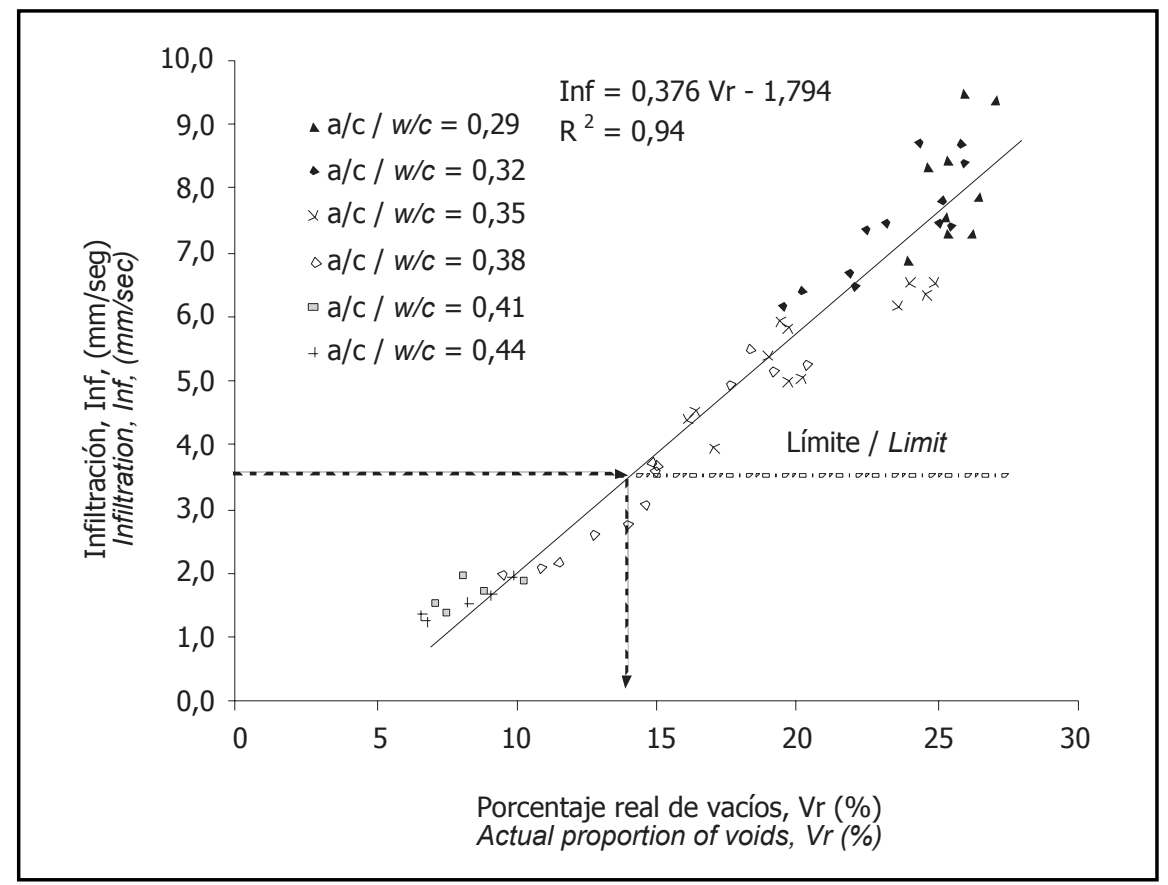

Figura 3. Relación entre la tasa de infiltración y el porcentaje real de huecos. Figure 3. Infiltration rate vs actual percentage of voids.

\subsection{Porcentaje real y teórico de huecos en las mezclas}

En la Figura 4 se presenta la relación entre el porcentaje teórico de huecos recalculado y el porcentaje real de huecos medido. El porcentaje teórico se recalculó utilizando el Factor de Compactación de cada mezcla, según su razón a/c.

La Figura muestra que, considerando todos los resultados, se tiene una relación lineal entre el porcentaje de huecos medidos y el porcentaje de huecos recalculados usando el FC experimental, pero diferente a la ecuación propuesta en investigaciones previas (FCPA, Ecuación [2]). Sin embargo, si sólo se consideran los resultados que satisfacen la condición mínima de infiltración de los pavimentos porosos $(\mathrm{Vr}>14 \%)$, la ecuación de regresión es muy similar a la Ecuación [2] usada en esta investigación. De este modo, los resultados experimentales permiten concluir que para los hormigones porosos, la ecuación utilizada es adecuada para relacionar el porcentaje de huecos reales y teóricos.

\subsection{Resistencia a flexotracción}

Dado que el factor de compactación resultó diferente al valor 0,95 inicialmente asumido, los porcentajes reales de huecos obtenidos fueron diferentes a los proyectados. Por esta razón no fue posible construir curvas de comportamiento mecánico para porcentajes constantes de huecos,

\subsection{Actual and theoretical void ratio}

Figure 4 shows the relationship between the re-calculated theoretical void ratio and the actual percentage measured in the concrete. The theoretical percentage of concrete voids was re-calculated using the actual compacting factor for each mixture, in keeping with the respective $w / c$ ratio.

The figure shows that when all the results are considered, the relationship between the measured percentage of voids and the ratio re-calculated using the experimental CF was linear, but different from the expression proposed in prior research (Equation 2, FCPA). If only the results that meet the minimum infiltration requirement $(\mathrm{Vr}>14 \%)$ for porous pavements are considered, however, the regression equation is very similar to the one used in this study. It may therefore be concluded from the experimental results that for porous concretes, Equation [2] suitably expresses the relationship between the actual and theoretical percentages of voids.

\subsection{Flexural strength}

Since the value of the compacting factor was not the 0.95 initially assumed, the actual void ratios differed from the projected values. Consequently, mechanical behaviour curves could not be plotted for constant void ratios, as initially intended. Rather, curves for constant 


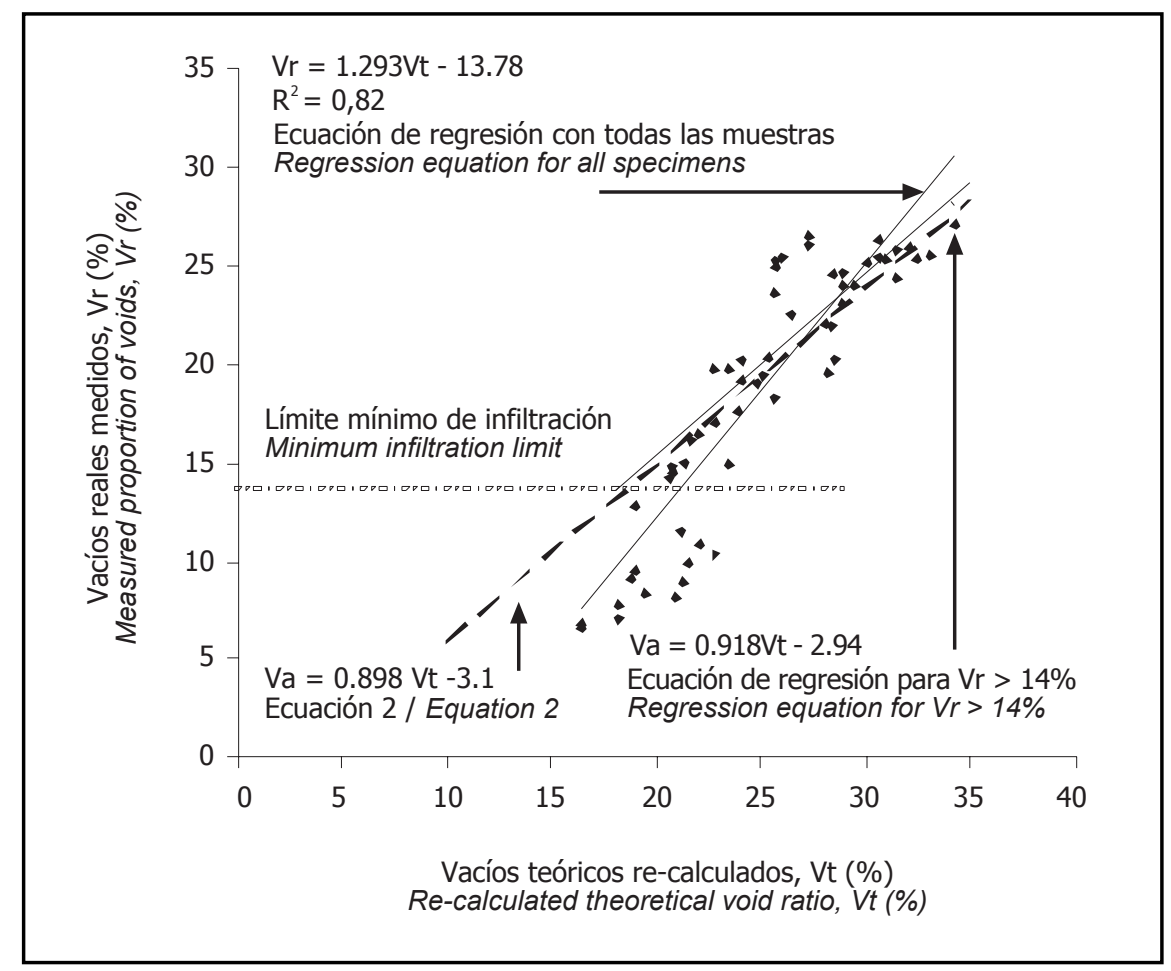

Figura 4. Relación entre el porcentaje real de huecos medidos y porcentaje teórico de huecos recalculado.

Figure 4. Measured void content vs re-calculated theoretical ratio.

como era la intención inicial, debiendo construirse curvas con razón a/c constante. En la Figura 5 se presentan los resultados de los ensayos de resistencia a flexotracción a 28 días, como función del contenido de cemento para razones a/c constantes. En esta figura, los números asociados a cada punto muestran el porcentaje real de huecos promedio medidos en el hormigón endurecido.

De la Figura 5 podría recomendarse no utilizar mezclas con razón a/c menor que 0,32 en pavimentos vehiculares, pues si bien pueden resultar con mayor cantidad de huecos, presentan bajas resistencias en comparación con las que utilizan razón a/c mayores o iguales que 0,35 . Además, se observaron inconvenientes como el desprendimiento del árido superficial por la escasa cantidad de pasta que puede retenerlos y la dificultad en la colocación debido a la sequedad de las mezclas.

De las curvas con razón a/c desde 0,29 hasta 0,38, a primera vista pareciera que la resistencia no sigue un patrón lógico. Para cada una de las curvas con razón a/c constante, cuando se incrementa el contenido de cemento, se obtiene una dosis que maximiza la resistencia, pero al agregar más cemento, la resistencia disminuye. Adicionalmente, la resistencia máxima es mayor a medida que aumenta la razón $\mathrm{a} / \mathrm{c}$, pero en contra de lo previsible, este aumento de la resistencia está asociado a una disminución de la cantidad de cemento. $w / c$ ratios had to be drawn. Figure 5 shows the results of the 28-day flexural strength tests against cement content for constant $w / c$ ratios. Each point on the figure represents the mean actual percentage of voids in the hardened concrete.

Pursuant to Figure 5, mixtures with a w/c ratio of under 0.32 should not be recommended for surfaces intended to support wheeled traffic, for while they may have more voids, their strength is lower than in concrete with $w / c$ ratios greater than or equal to 0.35 . Two additional problems were also observed with these mixtures: detachment of the surface aggregate due to insufficient paste to retain it and placement difficulties attributable to insufficient mix moisture.

The strength curves for mixtures with $\mathrm{w} / \mathrm{c}$ ratios from 0.29 to 0.38 do not appear to follow a logical pattern. The addition of cement initially increases strength, but after a given point, it causes flexural strength to decline. Furthermore, maximum strength grows with the w/c ratio, but this increase is associated with a drop in the amount of cement. 
Para entender esta situación consideraremos en primera instancia el comportamiento de las resistencias a flexotracción de mezclas con igual dosis de cemento. Puede observarse que a mayor razón a/c, mayor es la resistencia. Esto se puede explicar de un modo simple, pues al aumentar la razón a/c manteniendo la dosis de cemento constante, aumenta la cantidad de agua, mejorando la hidratación del cemento (considerando las bajas razones a/c) y aumentando el volumen de pasta, lo que permite mejorar las resistencias.

Para explicar la forma de cada curva de a/c constante se debe recordar que se está trabajando con granulometrías con un contenido elevado de huecos y que el volumen de pasta alcanza para llenar sólo cerca de la mitad de todos los huecos disponibles. Si bien en una probeta de hormigón tradicional el confinamiento lo entrega la pasta de cemento, que actúa como el medio en el cual las partículas se encuentran inmersas, el hormigón poroso está constituido por un verdadero esqueleto granular grueso en el que cada árido está apenas rodeado de mortero, razón por la cual la forma de los puentes o "meniscos" entre áridos, y la "trabazón" o transmisión de esfuerzos por contacto del árido, son muy importantes en la resistencia de estas mezclas (1).

Bajo esta consideración, si desde una condición de baja dosis de cemento (extremo izquierdo de las curvas de la Figura 5) se aumenta la cantidad de este pegamento sin
This behaviour is readily understood if considered from the standpoint of the flexural strengths of mixtures with the same cement dose. Note that the higher the $\mathrm{w} / \mathrm{c}$ ratio, the higher the strength. This can be explained rather simply, for a rising $w / c$ ratio at a constant cement dose generates mixtures with a higher water content, improving cement hydration (taking account of the low $\mathrm{w} / \mathrm{c}$ ratios) and increasing paste volume, which raises strength.

To explain the geometry of the constant $w / c$ ratio curves, attention is drawn to the fact that the mixtures in question have particle size distributions with large void ratios and the paste volume fills half or less of the voids. Whilst in a traditional concrete specimen, constraint is provided by the cement paste, which constitutes the medium in which the aggregate is immersed, porous concrete consists of a veritable granular skeleton in which each particle is barely covered by mortar. For this reason, the form of the bonds or "menisci" between aggregate and the "interlock" or transmission of stress across particles, are very important factors in the strength of these mixtures (1).

Consequently, if the amount of cement is increased in a mix having a low initial dose without altering the quality (constant w/c ratio) (left side of the curves in Figure 5),

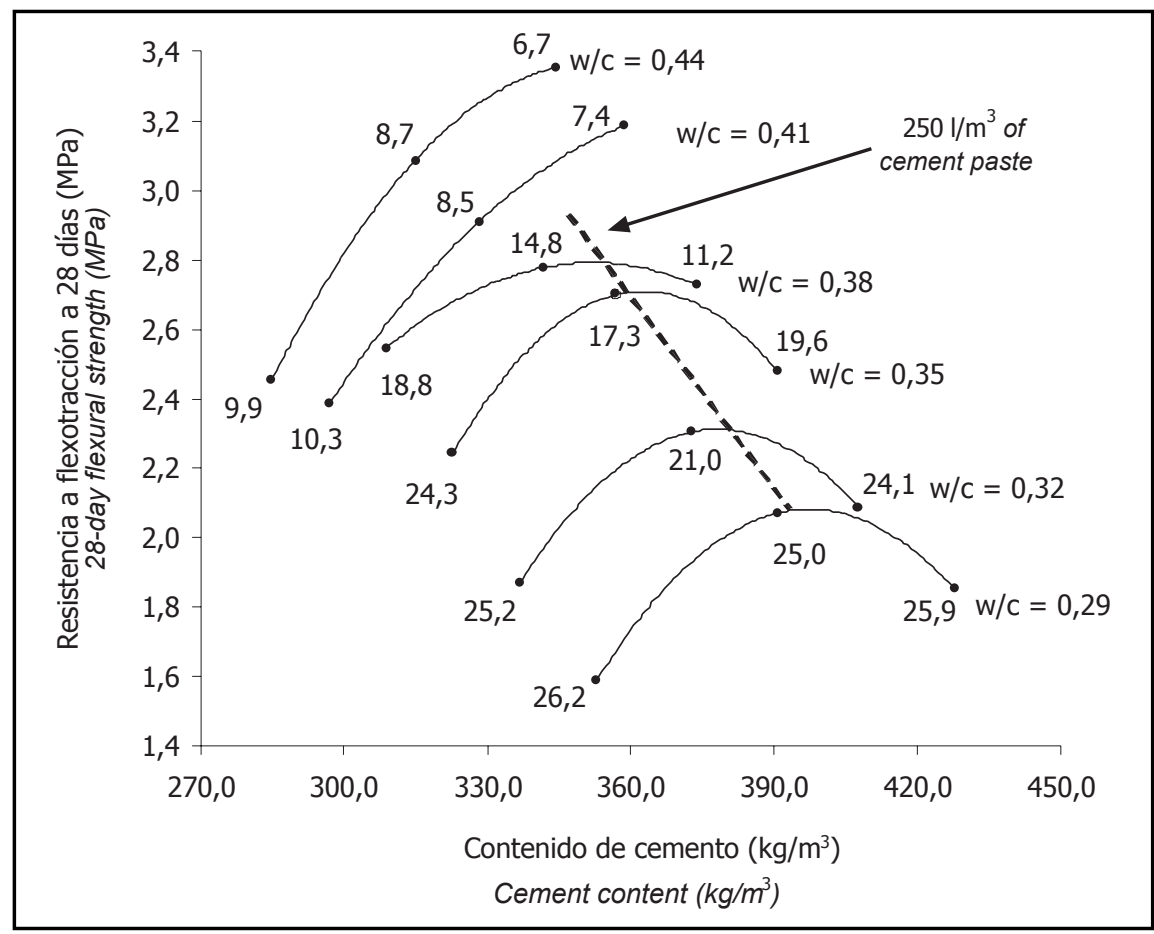

Figura 5. Efecto de la cantidad y calidad de pasta en la resistencia a flexotracción a 28 días.

Figure 5. Effect of cement paste quantity and quality on 28-day concrete flexural strength. 
alterar su calidad (razón a/c constante), la mezcla debería comenzar a resistir más. Sin embargo, si se sigue aumentando la cantidad de este pegamento, llegará un momento en que el aumento del volumen de pasta separará tanto las partículas que se producirá una disminución en la trabazón de la estructura con la consecuente pérdida de resistencia de la probeta, y se alteraría la forma de los "meniscos" (1), debilitando los puentes de unión entre áridos. El efecto combinado de ambas situaciones explicaría la disminución de las resistencias en la zona final del gráfico antes mencionado, justificándose de este modo la existencia de una dosis que maximiza la resistencia.

Asumiendo entonces que hay un espesor óptimo de la capa de pasta de cemento que maximiza la resistencia a la flexión del hormigón, se puede determinar el volumen de pasta asociado a cada dosis óptima de cemento. $A$ partir de la relación entre la resistencia a la flexotracción y el contenido de cemento para mezclas de igual razón $\mathrm{a} / \mathrm{c}$, se puede obtener la dosis óptima de cemento. El resultado de estos cálculos se muestra en la Tabla 2 para mezclas con razón a/c no mayores a 0,38.

Como muestra la Tabla 2, si bien las cantidades de cemento óptimas para cada razón a/c son diferentes, el volumen de pasta asociado es muy similar en todos los casos. De este modo se ratifica la hipótesis planteada, "la dosis óptima de cemento está determinada por el volumen de pasta adicionado a la mezcla", y éste resulta cercano a los 250 I o al $60 \%$ de los huecos disponibles en el árido, como lo muestra la línea segmentada en la Figura 5.

Podría pensarse también que a medida que se utilizan mayores razones a/c, la pasta se podría acomodar mejor dentro de los huecos del árido y separar menos las partículas (generando más huecos). Este comportamiento se refleja en cierta medida en los valores de FC medidos y en el aumento de resistencias observado en la Figura 5. Sin embargo, los resultados de la Tabla 2 muestran que el aumento del volumen requerido es bastante reducido y no afecta a la hipótesis de comportamiento. the paste should begin to gain in strength. As the amount of cement continues to grow, however, a point is reached where the increase in paste volume separates the particles so much that the interlock effect disappears, the flexural strength of the specimen declines and the shape of the "menisci" changes (1), weakening the interparticle bonds. The combined effect of these two developments would explain the decline in strength in the extreme right side of the above graph and the existence of an intermediate dose that maximizes strength.

Assuming therefore that the layer of cement paste has an optimum thickness that maximizes concrete flexural strength, the volume of paste associated with each optimum dose of cement can be determined. The optimum dose of cement can be found from the relationship between flexural strength and cement content for mixtures with a given $w / c$ ratio. The results of these calculations for mixtures with $w / c$ ratios no larger than 0.38 are given in Table 2.

As Table 2 shows, while the optimum cement content differs for each $w / c$ ratio, the associated volume of paste is similar in all cases. This confirms that the optimum cement dose is determined by the volume of paste added to the mix, which is around $250 \mathrm{l} / \mathrm{m}^{3}$ or $60 \%$ of the voids in the aggregate, represented by the broken line in Figure 5.

It might also be assumed that as the $\mathrm{w} / \mathrm{c}$ ratio rises, the paste could flow more readily into the voids without enlarging inter-void spacing. This behaviour is reflected to some extent in the measured CF values and the rise in strength observed in Figure 5. Nonetheless, the data in Table 2 show that the increase in volume required to attain maximum flexural strength is fairly small.

Tabla 2 / Table 2

Volumen de pasta asociado a las dosis óptimas de cemento

Cement paste volumes associated with optimum cement dose

\begin{tabular}{|c|c|c|}
\hline $\begin{array}{c}\text { Razón a/c } \\
\text { w/c ratio }\end{array}$ & $\begin{array}{c}\text { Dosis de cemento } \mathbf{( k g )} \\
\text { Optimum cement content } \\
\left(\mathbf{k g} / \mathbf{m}^{\mathbf{3}}\right)\end{array}$ & $\begin{array}{c}\text { Volumen de pasta (litros) } \\
\text { Optimum cement paste volume } \\
\left(\mathbf{(} / \mathbf{m}^{\mathbf{3}}\right)\end{array}$ \\
\hline 0.29 & 398 & 250 \\
\hline 0.32 & 378 & 249 \\
\hline 0.35 & 363 & 250 \\
\hline 0.38 & 352 & 253 \\
\hline
\end{tabular}




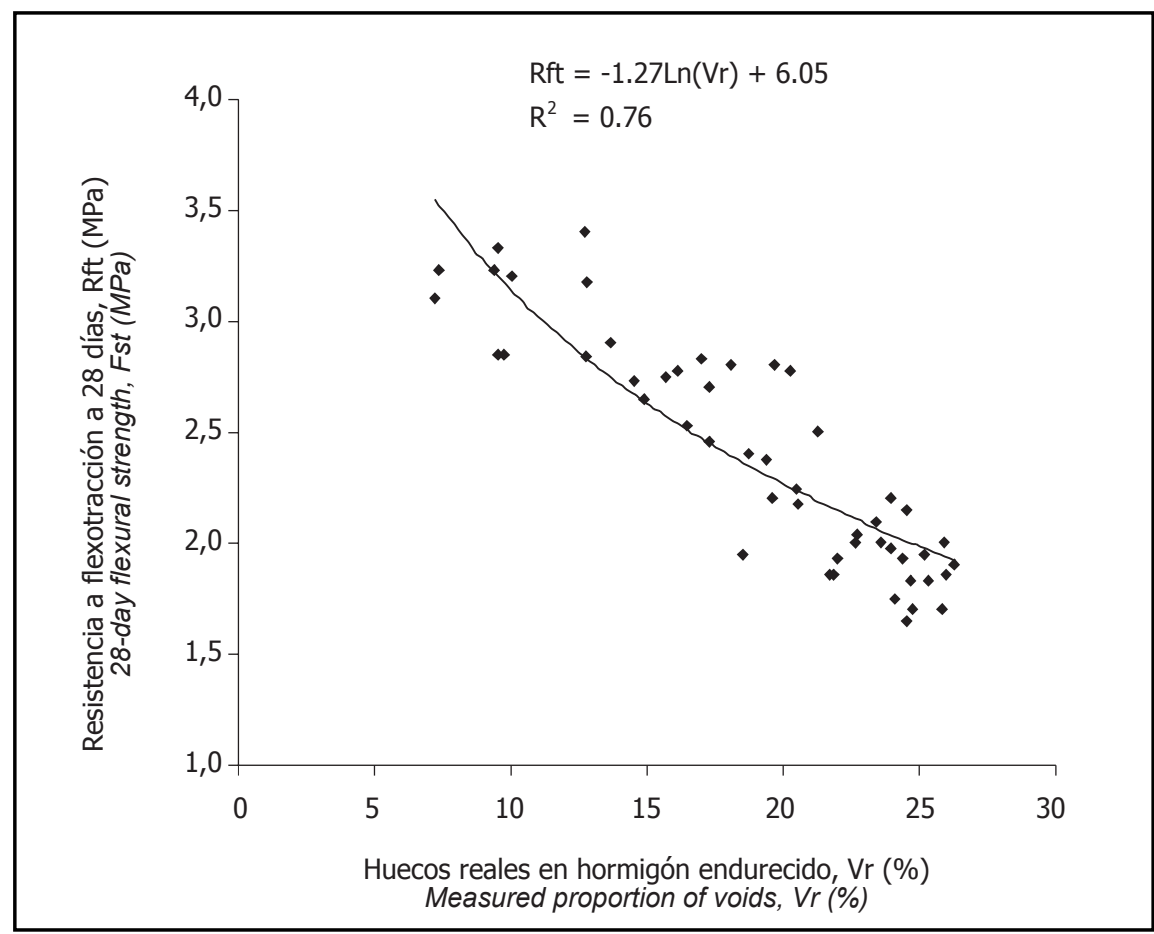

Figura 6. Relación entre resistencia a flexotracción a 28 días y porcentaje real de huecos. Figure 6. 28-day flexural strength vs actual void ratio.

Si bien todos los resultados han sido deducidos utilizando sólo un tipo de granulometría, sus resultados podrían extenderse a otras granulometrías en las que la trabazón siga siendo preponderante. Para eso se podría utilizar el concepto de superficie específica de los áridos, calculando el espesor de la pasta de cemento resultante (pegamento), como en métodos antiguos de dosificaciones.

Finalmente, en la Figura 6 se muestra una relación entre la resistencia a flexotracción a 28 días y el porcentaje real de huecos medidos para todas las probetas. Esta relación es muy útil para estimar la resistencia a flexotracción en terreno a través de la medición del porcentaje de huecos usando un permeámetro de carga variable.

\section{APLICACIÓN DE LA EXPERIENCIA}

Utilizando los resultados de esta investigación, se construyó un estacionamiento instrumentalizado para 4 automóviles, con una superficie de $60 \mathrm{~m}^{2}$, diseñado para comparar la capacidad de infiltración y los escurrimientos superficiales de estas estructuras con la de un pavimento de hormigón tradicional. Los resultados obtenidos durante 24 meses de funcionamiento muestran una excelente capacidad hidráulica acompañado de un muy buen desempeño funcional (6). En la Figura 7 se presentan dos fotografías de esta instalación.
Although all the foregoing results were found with only one particle size distribution, they may be extended to others where the interlock effect prevails. This would involve using the specific surface of the aggregate to calculate the resulting optimum thickness of the layer of cement paste, as in older dosing methods.

Finally, Figure 6 shows that the relationship between the 28-day flexural strength and the actual void ratio is linear for all the specimens tested. This relationship is very useful for field estimates of bending strength from void ratio measurements taken by a falling head permeameter.

\section{FIELD TRIALS}

A $60-m^{2}$ test car park for four vehicles was built on the basis of the results of this study to compare the permeability and runoff between this and traditional concrete pavements. The results obtained after 24 months in service revealed both excellent hydraulics and good operational performance (6). Two photographs of the facility are shown in Figure 7. 


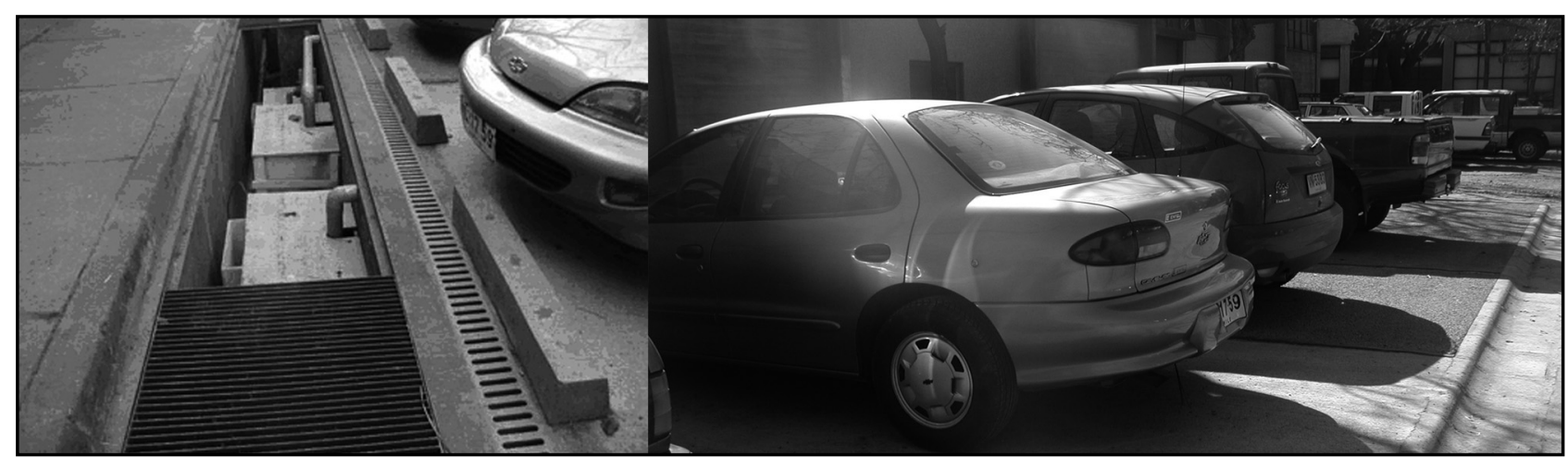

Figura 7. Instalación instrumentalizada de pavimentos porosos de hormigón.

Figure 7. Porous concrete pavement test parking lot.

\section{CONCLUSIONES}

A partir de los resultados obtenidos en laboratorio en esta investigación, se recomienda utilizar razones a/c entre 0,35 y 0,38 para mezclas de hormigón poroso. Mezclas con a/c menores presentan muy baja resistencia y apreciable desprendimiento superficial de áridos. Mezclas con a/c mayores presentan escurrimiento de la pasta de cemento y disminución notoria del porcentaje de huecos.

Para mezclas con razón a/c constante, existe una cantidad óptima de cemento que maximiza la resistencia a flexotracción. Este comportamiento puede ser explicado por el importante efecto de la trabazón de los áridos y el reducido volumen de pasta de cemento sobre la resistencia a flexotracción de estas mezclas.

Para que un hormigón sea considerado poroso, debe tener una tasa de infiltración mayor a 3,5 mm/s. Los resultados de esta investigación permiten concluir que las mezclas con porcentajes de huecos mayores a $14 \%$ satisfacen dicha condición. Para medir la capacidad de infiltración de estas mezclas, se utilizó un permeámetro de carga variable. Este equipo permite calcular directamente la tasa de infiltración y el porcentaje de huecos reales presentes en el hormigón, usando ecuaciones de regresión.

Entre las mezclas de hormigón que pueden ser consideradas porosas, las más resistentes se obtienen utilizando una razón $\mathrm{a} / \mathrm{c}$ de 0,38 , una dosis de cemento de 350 kilogramos y adicionando un aditivo plastificante al 0,5\% del peso del cemento. Esta dosificación permite obtener resistencias en terreno cercanas a los 2,8 MPa y un porcentaje de huecos del orden del $14 \%$. Mezclas de hormigón poroso con porcentajes de huecos de $20 \%$ garantizan resistencias superiores a 2,3 MPa a flexotracción, y que optimizan el uso de cemento, se obtienen con dosis de cemento cercanas a 320 kilogramos usando una razón a/c igual a 0,35.

\section{CONCLUSIONS}

Based on the laboratory results obtained in this study, $w / c$ ratios of between 0.35 and 0.38 are recommended for porous concrete mixtures. Concretes with lower ratios exhibit very low strength and perceptible aggregate detachment, while in mixes with higher ratios the cement paste tends to flow more freely, substantially reducing the void ratio.

The existence of an optimum amount of cement for each $w / c$ ratio that maximizes bending strength can be explained by the combined effect of aggregate interlock and the small volume of cement paste on the flexural strength of these mixtures.

Porous concrete is defined to be concrete with an infiltration rate of over $3.5 \mathrm{~mm} / \mathrm{s}$. It may be concluded from the results of the present study that mixtures with void ratios of over $14 \%$ meet this requirement. Mixture permeability was measured with a falling head permeameter, an instrument that uses regression equations to calculate the infiltration rate and actual void ratio in concrete.

Of the concretes meeting the porous definition requirement, the strongest had a w/c ratio of 0.38 , a cement dose of $350 \mathrm{~kg}$ and $0.5 \%$ of water-reducing admixture, by cement weight. The field strength attained with this dose was on the order of $2.8 \mathrm{MPa}$, with a void ratio of around $14 \%$. Porous concrete mixtures with void ratios of $20 \%$, however, exhibited flexural strengths of over 2.3 MPa while optimizing cement use, as they were obtained with a cement dose of around $320 \mathrm{~kg}$ and a $w / \mathrm{c}$ ratio of 0.35 . 
A partir de los resultados de la Tabla 2 se puede desarrollar un método de dosificación para otros áridos que considere su superficie específica y el espesor de la pasta de cemento.

\section{AGRADECIMIENTOS}

Agradecemos el importante apoyo financiero del proyecto FONDEF "Sistemas estandarizados para soluciones de aguas lluvias", y a DICTUC SA por facilitarnos sus laboratorios para el desarrollo de esta investigación. Agradecemos también a la compañía Cementos Lafarge, por su apoyo técnico y financiero. El trabajo expuesto forma parte de la tesis del señor Javier Castro para obtener el grado Magíster de la Universidad Católica de Chile.
The results in Table 2 could potentially be used to develop a dosing method for other particle size distributions based on specific surface and the thickness of the layer of cement paste.

\section{ACKNOWLEDGEMENTS}

The authors gratefully acknowledge the important financial support of FONDEF through the grant project "Standardized systems for water down rains solutions" and to DICTUC SA for its contribution in terms of laboratory facilities to carry out this research. Grateful acknowledge is also made to Lafarge Cement Company for its financial and technical support. The work reported herein was carried out by Javier Castro in fulfillment of a MS in civil engineering, Universidad Católica de Chile.

\section{BIBLIOGRAFÍA / BIBLIOGRAPHY}

(1) Fernández Luco, L., Vitola, L. y Salminci, P.: "Estado del arte en el uso de hormigones porosos", XII Congreso Argentino de Vialidad y Tránsito, Buenos Aires, Argentina, Tomo II, p. 761. (Trabajo publicado posteriormente por la Revista Carreteras, Año XLVI, no 160, marzo de 2000.)

(2) Ghafoori, N. y Dutta, S.: "Pavement thickness design for no-fines concrete parking lots", Journal of Transportation Engineering, vol. 121, no 6 (1995), pp. 476-484.

(3) GCPA: Recommended Specifications for Portland Cement Pervious Pavement, Georgia Concrete and Products Association, Inc, 1997 (www.pervious.info).

(4) FCPA: Portland Cement Pervious Pavement Manual, Florida Concrete and Products Association, Inc. Florida, 1990.

(5) Meininger, R.: "No-Fines Pervious Concrete for Paving", Concrete International, vol. 10, no 8 (1988), pp. 20-27.

(6) Castro, J.: "Diseño de mezcla y construcción de pavimentos de hormigón poroso en Chile", Tesis de Magíster, Pontificia Universidad Católica de Chile, 2004, 188 pp.

(7) Kwiatkowski, M. y Welker, A.: "Development of a Monitoring Program for a Porous Concrete BMP", World Water and Environmental Resources Congress, Philadelphia, Pennsylvania, 2003.

(8) Reyes, F. y Torres, A.: "Effect of plastic fibers on flexion of drainable pavement structures", Revista Ingeniería de Construcción, vol. 17 , no 2, mayo-agosto de 2002, pp. 93-102. 